\begin{tabular}{c} 
Volume and Issues Obtainable at Center for Sustainability Research and Consultancy \\
Journal of Accounting and Finance in Emerging Economies \\
ISSN: 2519-0318 ISSN (E) 2518-8488 \\
Volume 7: Issue 1 March 2021 \\
CSRC \\
Journal homepage: www.publishing.globalcsrc.org/jafee \\
\hline
\end{tabular}

\title{
Anticipated Volatility, Unanticipated Volatility Shocks, Excess Monthly Returns and Stock Market Behavior of Pakistan
}

\begin{tabular}{|c|c|}
\hline \multicolumn{2}{|c|}{ 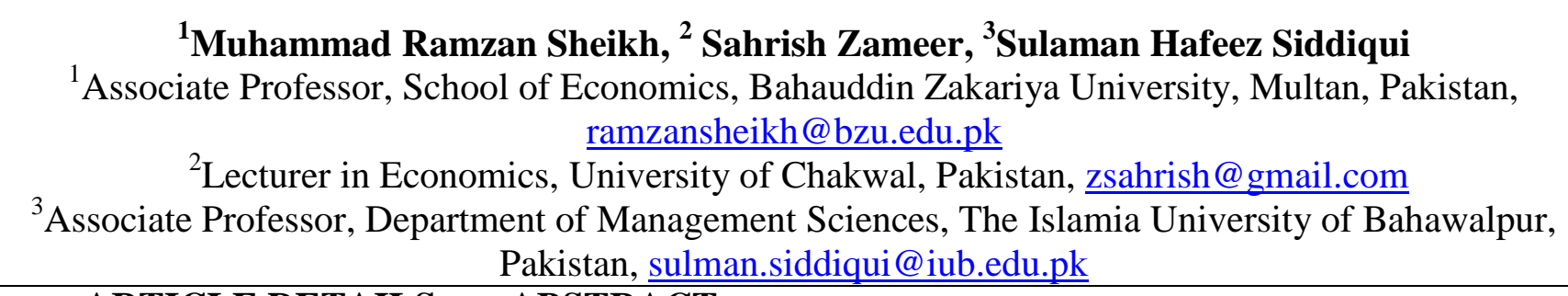 } \\
\hline ARTICLE DETAILS & ABSTRACT \\
\hline History & An investor considers $\mathrm{v}$ \\
\hline Revised format: January 2021 & The portfolio theory suggests that risk, return, taxes, information and \\
\hline Available Online: March & liquidity are vital factors in portfolio choice. The study is based on \\
\hline 2021 & risk premium, uncertainty, shocks and volatility of Pakistan stock \\
\hline Keywords & exchange market. The study has used monthly time series data of \\
\hline $\begin{array}{l}\text { Volatility, Shocks, Returns, } \\
\text { Stock Market. }\end{array}$ & $\begin{array}{l}\text { returns of ten sectors of Pakistan stock market ranging from } 2006 \text { to } \\
2014 \text { to measure the anticipated and unanticipated factors of risk, } \\
\text { return and uncertainty. Using CAPM, it is pointed out that volatility }\end{array}$ \\
\hline $\begin{array}{l}\text { JEL Classification: } \\
M 40, M 41\end{array}$ & $\begin{array}{l}\text { factor is present and high in overall stock market and the level of } \\
\text { volatility in different sectors of the market moves in the same } \\
\text { direction which suggest that speculative activities are widely spread } \\
\text { in every sector and in overall market as well. }\end{array}$ \\
\hline ACCESS & $\begin{array}{r}\text { (C) } 2020 \text { The authors, under a Creative Commons Attribution- } \\
\text { NonCommercial } 4.0\end{array}$ \\
\hline
\end{tabular}

Corresponding author's email address: ramzansheikh@bzu.edu.pk

Recommended citation: Sheikh, M. R., Zameer, S. \& Siddiqui, S. H. (2021). Anticipated Volatility, Unanticipated Volatility Shocks, Excess Monthly Returns and Stock Market Behavior of Pakistan. Journal of Accounting and Finance in Emerging Economies, 7(1), 77-91

\section{Introduction}

Risk theory states that the investors are unwilling to invest in a risky asset due to fear of loss of their wealth unless they ensure that their risk will be compensated. The difference between the returns of on risky asset and risk-free asset is known as risk premium. According to the CAPM, as risk increases in financial market, the return on risky assets also increases. If this proposition does not hold, it means that the investors do not have complete information, or they are risk neutral (Ahmad and Zaman, 2000).

Karachi Stock Exchange has been classified on of the best and emerging financial markets during 1990s. To observe the variations in the prices of stocks, uncertainty, volatility in Karachi Stock Exchange, various studies have been conducted. Khiliji and Nabi (1993) have measured the monthly stock returns for the period of 1981-1992 by using CAPM model but they have only measured the stock prices in overall market and point out that values of beta coefficients are near to one indicating that same risk within industries and across the industries. The study has also inferred that Pakistan's financial market is efficient as short run and long run expected returns equal to each other. 
Ahmed and Rosser (1995) using VAR technique have measured the non-speculative activities of Pakistan stock market. Ahmad and Zaman (1999) have examined the relationship between volatility and stock returns in Karachi stock market using CAPM model. Ahmad and Zaman $(1999,2000)$ are the first who have studied the whole relationship of risk, return and uncertainty for Karachi stock market from 1992 to1997 using CAPM model and measure the risk premium on asset with beta parameter and infer that Karachi stock market is efficient. Nishat and Mustafa (2010) have measured the relationship between the risk, return and trading volume using GARCH-M model and reveal that there is a significant effect on prices, return and trading activity. Hamid (2015) has investigated the relationship between risk and return in Pakistan stock market using CAPM, DR-CAPM and GMM model and point out that there is a high volatility in Pakistan stock market. Khan (2016) using ARCH, GARCH, and EWMA model has computed the daily, weekly and monthly volatility on stocks and returns. Khan and Hijazi (2019) using OLS model have examined the effects of stock on future trading and volatility.

All these studies exhibit that the various researchers have used diverse methods to measure the risk, return of stocks in Karachi Stock Market of Pakistan.

This study is based on the estimation of risk premium, uncertainty and risk on asset, return on asset, shocks and volatility from the various sectors and in overall market by using CAPM model. The main objective of this study is to measure the effectiveness of returns and risk of stock by including anticipated and unanticipated factors of risk and uncertainty. It is important for every country that its financial market should be efficient, so we have measured the efficiency of Pakistan Stock Market. Moreover, we have also observed the magnitude of beta in a specific sector to examine the risk factor along with the calculation of the movement of trends in various sectors. The specific objectives of the study are:

- To compute the appropriate integrated Moving average processes of different orders for various sectors.

- To estimate the standard deviation on monthly returns by sub-dividing the monthly returns into anticipated and unanticipated factors for the estimation of volatility shocks and uncertainty.

- To analyze the relationship between risk and returns on individual sectors and whole market.

- To measure the flow of trends and market efficiency between returns on individual sectors and whole market and analyze the direction of their movement.

- To calculate the volatility between sectors and the whole market.

The structure of this study is organized as: Review of assorted studies is given in section 2. Section 3 elaborates the theoretical framework in the form of Capital Asset Pricing Model. Section 4 contain the data and methodology while section 5 gives the estimation of results and discussions. Section 6 concludes the study along with policy implications.

\section{Review of Assorted Studies}

This section consists of the summary of empirical studies based on uncertainty, risk and return. Table 1 displays the synopsis of studies based on Pakistan and other countries' stock exchange market, studies based on volatility and non-volatility stock market, studies based on equity, bonds and share prices and studies based on risk and return of stock market.

Table 1: Summary of Studies

\begin{tabular}{|c|c|c|c|c|}
\hline Reference(s) & Country & $\begin{array}{l}\text { Time Period } \\
\text { covered }\end{array}$ & Methodology & Main results \\
\hline \multicolumn{5}{|c|}{ Studies based on Pakistan and other countries Stock Exchange Market } \\
\hline $\begin{array}{l}\text { Abounoori } \\
\text { Tour (2019) }\end{array}$ & $\begin{array}{l}\text { and Iran, USA, Turkey, } \\
\text { and UAE }\end{array}$ & 2008 to 2017 & $\begin{array}{l}\text { ARCH and GARCH } \\
\text { model }\end{array}$ & $\begin{array}{l}\text { The shock and } \\
\text { volatility effects } \\
\text { were positive in } \\
\text { stock market. }\end{array}$ \\
\hline
\end{tabular}




\begin{tabular}{|c|c|c|c|c|}
\hline $\begin{array}{l}\text { Gourene, Mendy } \\
\text { and Ake (2018) }\end{array}$ & $\begin{array}{l}\text { Emerging markets } \\
\text { (Brazil, Russia, } \\
\text { India and China) } \\
\text { and developed } \\
\text { markets (US, UK, } \\
\text { France, Germany } \\
\text { and Japan }\end{array}$ & 2005 to 2018 & $\begin{array}{l}\text { MODWT } \\
\text { (Maximum Overlap } \\
\text { Discrete Wavelet } \\
\text { Transform model) }\end{array}$ & $\begin{array}{l}\text { Correlation of } \\
\text { return and oil price } \\
\text { was inverse. }\end{array}$ \\
\hline $\begin{array}{ll}\text { Javaira } & \text { and } \\
\text { Hassan (2015) } & \end{array}$ & Pakistan & 2002 to 2007 & CSSD & $\begin{array}{lr}\text { Stock prices } & \text { were } \\
\text { positively } & \\
\text { interrelated } & \text { with } \\
\text { both equity return } \\
\text { dispersion } & \text { and } \\
\text { asymmetric } & \\
\text { behavior. } & \end{array}$ \\
\hline $\begin{array}{l}\text { Raza, Jawaid, } \\
\text { Afshan, } \quad \text { Karim } \\
(\mathbf{2 0 1 5})\end{array}$ & Pakistan & 1976 to 2011 & ARDL & $\begin{array}{l}\text { The relation } \\
\text { between stock } \\
\text { market } \\
\text { capitalization and } \\
\text { foreign capital } \\
\text { inflows, workers } \\
\text { remittances, } \\
\text { economic growth } \\
\text { was positive both in } \\
\text { long and short run. }\end{array}$ \\
\hline Sharif (2015) & Pakistan & $\begin{array}{l}1 \text { July } 2008 \text { to } 31 \\
\text { January } 2009\end{array}$ & AR and CAR model & $\begin{array}{l}\text { Negative effects } \\
\text { arise when price } \\
\text { floor was imposed } \\
\text { in the market. }\end{array}$ \\
\hline $\begin{array}{l}\text { Rahman } \\
\text { Mohsin (2012) }\end{array}$ & Pakistan & 1999 to 2007 & $\begin{array}{l}\text { Weighted and } \\
\text { Decile technique }\end{array}$ & $\begin{array}{l}\text { Zero cost } \\
\text { momentum effect } \\
\text { was very positive } \\
\text { for long term in the } \\
\text { stock market. }\end{array}$ \\
\hline $\begin{array}{l}\text { Javed and Ahmad } \\
\text { (2011) }\end{array}$ & Pakistan & 1993 to 2007 & $\begin{array}{lr}\text { EGARCH } & \text { model } \\
\text { and } & \text { FAMA } \\
\text { FRECNH } & \text { three } \\
\text { factors model } & \end{array}$ & $\begin{array}{l}\text { Beta was positively } \\
\text { related with return } \\
\text { at high market while } \\
\text { the relation between } \\
\text { Beta and return on } \\
\text { low market was } \\
\text { inverse. }\end{array}$ \\
\hline $\begin{array}{l}\text { Sohail and Hussain } \\
(2009)\end{array}$ & Pakistan & 2002 to 2008 & VECM method & $\begin{array}{l}\text { Stock returns } \\
\text { influence negatively } \\
\text { in consumer sector } \\
\text { while relationship } \\
\text { of stock return with } \\
\text { real effective } \\
\text { exchange rate and } \\
\text { money supply was } \\
\text { positive in industrial } \\
\text { sector. }\end{array}$ \\
\hline $\begin{array}{l}\text { Zou and Adam } \\
(2008)\end{array}$ & China & 1996 to 2000 & OLS model & $\begin{array}{l}\text { Volatility was } \\
\text { inversely related } \\
\text { with stock returns. }\end{array}$ \\
\hline Moore (2007) & $\begin{array}{l}\text { Hungary, } \\
\text { and UK }\end{array}$ & 1999-2005 & GARCH & $\begin{array}{l}\text { Interrelation at } \\
\text { exchange rate and } \\
\text { Hungary return was } \\
\text { positive while } \\
\text { exchange rate was } \\
\text { negatively } \\
\text { correlated with } \\
\text { Poland return. }\end{array}$ \\
\hline Akmal (2007) & Pakistan & 1971 to 2006 & ARDL & There was \\
\hline
\end{tabular}




\begin{tabular}{|c|c|c|c|c|}
\hline & & & cointegration model & $\begin{array}{l}\text { negative relation } \\
\text { between inflation } \\
\text { and stock prices. }\end{array}$ \\
\hline Robinson (2005) & Jamaica & $\begin{array}{l}2 \text { January } 1992 \text { to } \\
31 \text { December } 2001\end{array}$ & $\begin{array}{l}\text { Autocorrelation test } \\
\text { and run test }\end{array}$ & $\begin{array}{lr}\text { Stock } & \text { prices } \\
\text { positively } & \\
\text { influenced } & \text { in } \\
\text { Jamaica } & \text { stock } \\
\text { returns. } & \\
\end{array}$ \\
\hline Khan (2004) & Pakistan & 1980 to 1999 & $\begin{array}{l}\text { Cointegration } \\
\text { method }\end{array}$ & $\begin{array}{l}\text { The relation } \\
\text { between stock } \\
\text { prices and inflation } \\
\text { was positive. }\end{array}$ \\
\hline $\begin{array}{l}\text { Farooq and Keung } \\
\text { (2004) }\end{array}$ & Pakistan & 1994 to 2003 & $\begin{array}{l}\text { Granger test and } \\
\text { cointegration } \\
\text { method }\end{array}$ & $\begin{array}{l}\text { The relation } \\
\text { between stock } \\
\text { prices and exchange } \\
\text { rate in long run was } \\
\text { negative while the } \\
\text { relation between } \\
\text { stock prices and } \\
\text { exchange rate in } \\
\text { short run was } \\
\text { positive. }\end{array}$ \\
\hline $\begin{array}{l}\text { Hussain and } \\
\text { Muhammad (2001) }\end{array}$ & Pakistan & 1960 to 1999 & $\begin{array}{l}\text { Cointegration and } \\
\text { error correction } \\
\text { model }\end{array}$ & $\begin{array}{lr}\text { Stock prices } & \text { were } \\
\text { positively } & \text { related } \\
\text { with } & \text { both } \\
\text { consumption } & \\
\text { expenditures } & \text { and } \\
\text { investment } & \\
\text { spending. } & \end{array}$ \\
\hline $\begin{array}{l}\text { Dockery ,Vergari } \\
\text { and Vergari (2001) }\end{array}$ & Greek & 1988 to 1994 & $\begin{array}{l}\text { Variance Ratio test } \\
\text { and Robinson's LM } \\
\text { test. }\end{array}$ & $\begin{array}{l}\text { Stock prices of } \\
\text { individual sector } \\
\text { were inversely } \\
\text { related with stock } \\
\text { prices of overall } \\
\text { market. }\end{array}$ \\
\hline $\begin{array}{ll}\text { Atindéhou } & \text { and } \\
\text { Gueyie(2001) } & \end{array}$ & $\begin{array}{l}\text { Canadian chartered } \\
\text { banks }\end{array}$ & 1988 to 1995 & Three-factor model & $\begin{array}{l}\text { There was positive } \\
\text { relationship } \\
\text { between returns and } \\
\text { market indices } \\
\text { while negatively } \\
\text { relationship among } \\
\text { returns and interest } \\
\text { rate. Exchange rate } \\
\text { was depreciated } \\
\text { with negative } \\
\text { reactions of } \\
\text { investors. }\end{array}$ \\
\hline $\begin{array}{l}\text { Hussain and Upal } \\
\text { (1998) }\end{array}$ & Pakistan & $\begin{array}{l}\text { 1, January } 1989 \text { to } \\
\text { 30, Dec } 1993\end{array}$ & $\begin{array}{l}\text { Fama French model } \\
\text { and JB Test }\end{array}$ & $\begin{array}{l}\text { Market stock return } \\
\text { was inversely } \\
\text { reacted with prices } \\
\text { of stocks and bonds }\end{array}$ \\
\hline Aggarwal (1979) & US & 1964 to 1974 & CAPM model & $\begin{array}{l}\text { Company share } \\
\text { prices, US stock } \\
\text { market and risk had } \\
\text { negative bonding. }\end{array}$ \\
\hline \multicolumn{5}{|c|}{ Studies Based on Volatility and Non-Volatility Stock Market } \\
\hline $\begin{array}{l}\text { Khan and Hijazi } \\
(2019)\end{array}$ & Pakistan & 1999 to 2008 & OLS & $\begin{array}{l}\text { Volatility had } \\
\text { positively related } \\
\text { with stock prices. }\end{array}$ \\
\hline $\begin{array}{l}\text { Tissaoui and Azibi } \\
\text { (2018) }\end{array}$ & Saudi stock market & $\begin{array}{l}8 \text { January } 2008 \text { to } \\
31 \text { October }\end{array}$ & $\begin{array}{l}\text { GARCH } \\
\text { model }\end{array}$ & $\begin{array}{lr}\text { Risky assets } & \text { were } \\
\text { negatively } & \\
\text { interrelated } & \text { on }\end{array}$ \\
\hline
\end{tabular}


Saudi stock returns.

Prasad et al. (2018) Australia, Brazil, January 6, 2000 to GARCH model In American and Canada, China, June 13, $2014 \quad$ European stock

France, $\quad$ market, volatility Germany, Hong effect was very high Kong, India, Japan, and positive

Korea, Mexico,

Spain, Switzerland,

Taiwan, UK and

USA

\begin{tabular}{lll}
\hline Lyocsal et al. & U.S, Canada, Japan \\
(2018) & & U. K., Germany \\
& France, Italy and \\
& Eurozaone
\end{tabular}

2006 to 2016

GARCH model

There was negative relationship

between interest rate and return on stock while there was positive relationship between return on stock and volatility prices.

\begin{tabular}{|c|c|c|c|c|}
\hline Khan (2016) & Pakistan & 1991 to 2013 & $\begin{array}{l}\text { ARCH, GARCH } \\
\text { and EWMA }\end{array}$ & $\begin{array}{lr}\text { There was a high } \\
\text { volatility } & \text { in } \\
\text { Pakistan } & \text { stock } \\
\text { market. } & \end{array}$ \\
\hline $\begin{array}{l}\text { Singhania and } \\
\text { Prakash (2014) }\end{array}$ & $\begin{array}{lr}\text { SAARC } & \text { nations } \\
\text { (Pakistan, } & \text { India, } \\
\text { Bangladesh } & \text { and } \\
\text { Srilanka) } & \end{array}$ & 2000 to 2011 & GARCH model & $\begin{array}{l}\text { Stock return were } \\
\text { positively linked } \\
\text { with both } \\
\text { conditionally and } \\
\text { unconditionally } \\
\text { volatility. }\end{array}$ \\
\hline $\begin{array}{l}\text { Messis and } \\
\text { Zapranis (2014) }\end{array}$ & $\begin{array}{l}\text { Athens } \\
\text { Market }\end{array}$ & 1995 to 2010 & CAPM & $\begin{array}{l}\text { Responses of stock } \\
\text { prices and volatility } \\
\text { moved in the same } \\
\text { direction. }\end{array}$ \\
\hline Fu et al. (2011) & $\begin{array}{l}\text { Japanese } \\
\text { Foreign } \\
\text { market }\end{array}$ & 1994 to 2007 & GARCH model & $\begin{array}{l}\text { Volatility } \\
\text { transmission was } \\
\text { positively related in } \\
\text { Japanese stock } \\
\text { market and foreign } \\
\text { stock market while } \\
\text { there was negative } \\
\text { relation between } \\
\text { volatility } \\
\text { transmission and } \\
\text { asymmetric effects. }\end{array}$ \\
\hline $\begin{array}{ll}\text { Ahmad } & \text { and } \\
\text { Zaman (1999) } & \end{array}$ & Pakistan & 1992 to 1997 & $\begin{array}{l}\text { Capital } \\
\text { Pricing } \\
(\mathrm{CAPM})\end{array}$ & $\begin{array}{l}\text { There was a } \\
\text { positive relationship } \\
\text { between risk and } \\
\text { return in stock } \\
\text { prices. There was a } \\
\text { negative } \\
\text { relationship } \\
\text { between less risky } \\
\text { assets and rate of } \\
\text { returns. }\end{array}$ \\
\hline $\begin{array}{l}\text { Ahmed and Rosser } \\
\text { (1995) }\end{array}$ & Pakistan & 1987 to 1993 & $\begin{array}{l}\text { VAR technique and } \\
\text { Hamilton switching } \\
\text { model }\end{array}$ & $\begin{array}{l}\text { Positive link in } \\
\text { stock prices and } \\
\text { exchange rate }\end{array}$ \\
\hline \multicolumn{5}{|c|}{ Studies based on Equity, Bonds and Share } \\
\hline $\begin{array}{l}\text { Shahzad et } \\
(2017)\end{array}$ & $\begin{array}{l}\text { Developed markets } \\
\text { (USA, UK, Japan, } \\
\text { Canada, }\end{array}$ & 2009 & $\begin{array}{l}\text { QQ (Quintile-on- } \\
\text { Quintile) }\end{array}$ & $\begin{array}{l}\text { There was positive } \\
\text { link at stock bond } \\
\text { and stock market. }\end{array}$ \\
\hline
\end{tabular}


Germany. Eurozone

countries (Greece,

Ireland, Portugal,

Spain and Ireland)

Demirovic et al. US stock market

1996 to 2011

GARCH $(1,1)$

The average

correlation between

(2017)

bond and equity was

positive. There was

negative equity

volatility between

bonds and equity

and negative

relation between

credit risk and two

securities.

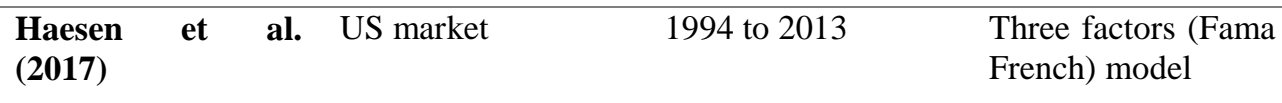

There was a

negative relation

between equity

return and default

risk in a traditional

momentum

spillover.

Lin et al. (2017) $\quad$ USA 1998 to $2014 \quad$ Wavelet Analysis Negative effects method were measured at

stock return and stock and bond in long term when there were crises in economy.

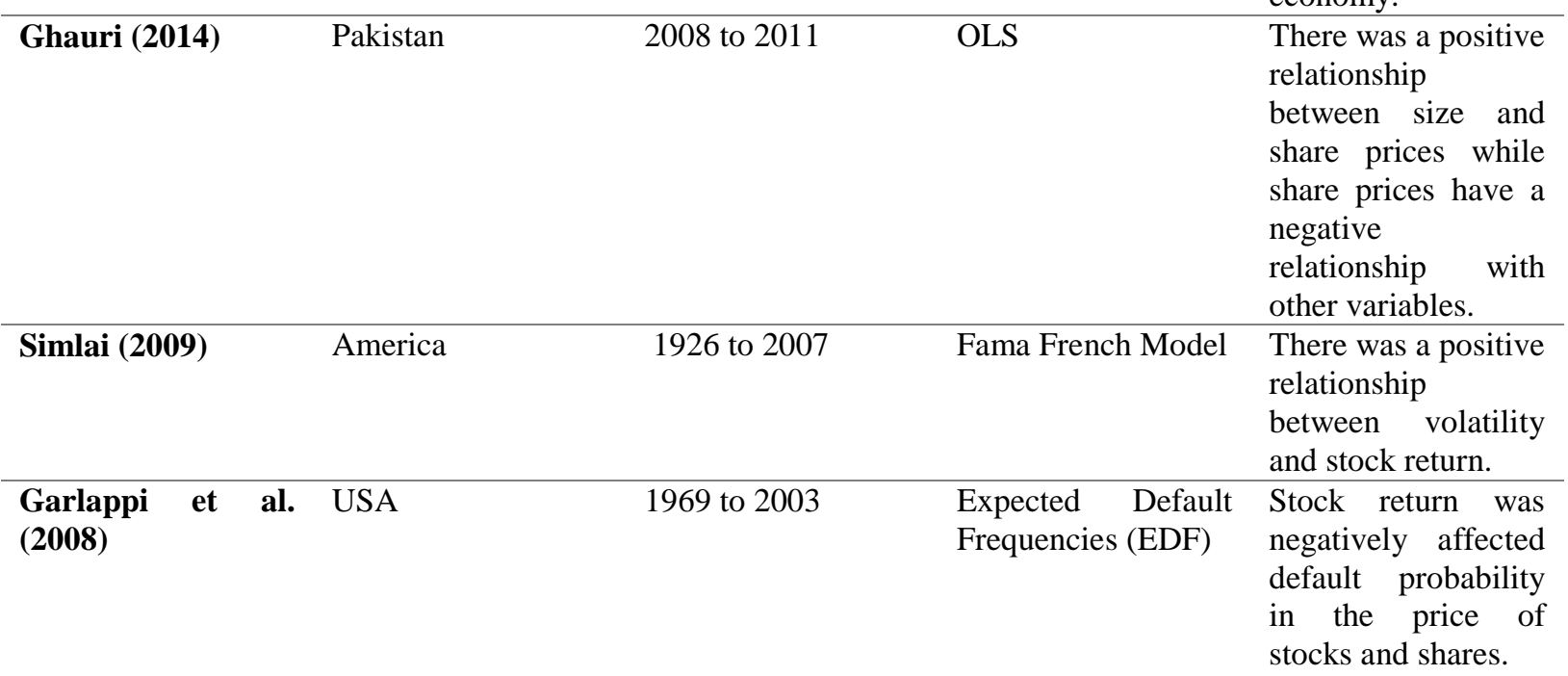

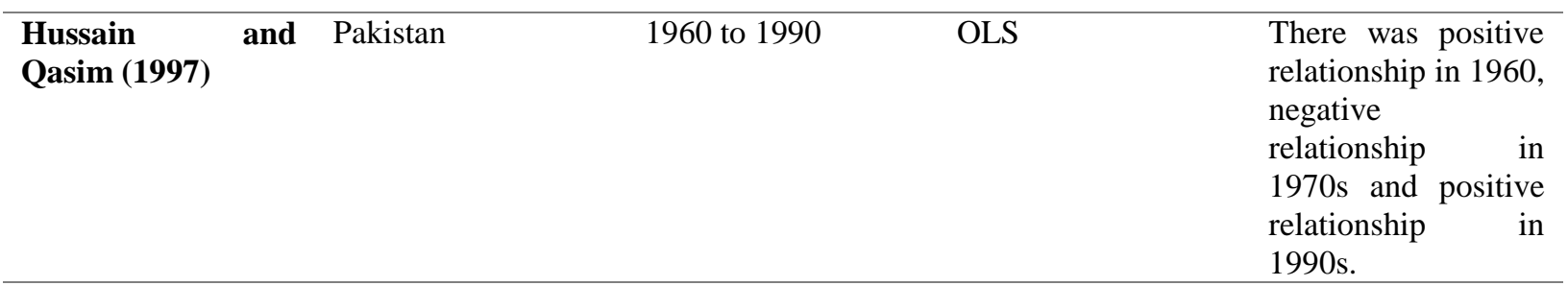

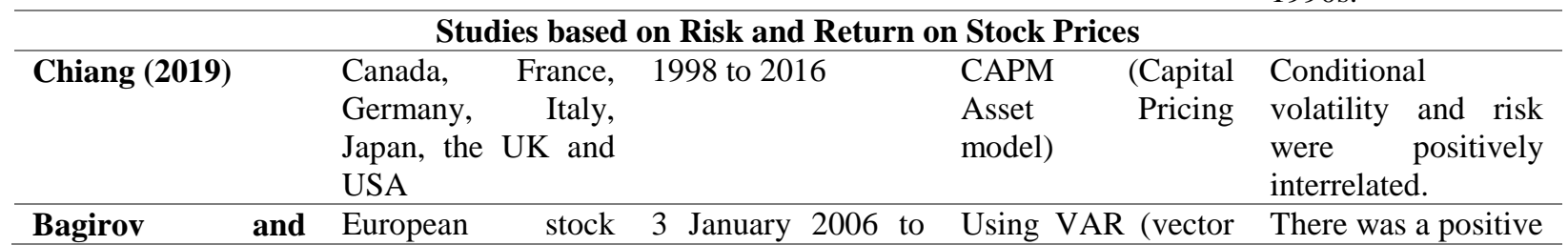




\begin{tabular}{|c|c|c|c|c|}
\hline Mateus (2019) & market & 29 December 2015 & $\begin{array}{l}\text { auto regressive } \\
\text { model), } \quad \text { VAR- } \\
\text { GARCH model, and } \\
\text { GMM model. }\end{array}$ & $\begin{array}{l}\text { relation between } \\
\text { change in oil prices } \\
\text { and list of financial } \\
\text { firms while there } \\
\text { was a negative } \\
\text { relation between } \\
\text { change in crude oil } \\
\text { prices and financial } \\
\text { performance of } \\
\text { unlisted firms. }\end{array}$ \\
\hline $\begin{array}{l}\text { Maghyereh and } \\
\text { Al-Zoubi (2018 }\end{array}$ & $\begin{array}{l}\text { Gulf states } \\
\text { (Bahrain, Kuwait, } \\
\text { Oman, Qatar, Saudi } \\
\text { Arabia and United } \\
\text { Arab Emirates) }\end{array}$ & 1998 to 2005 & $\begin{array}{l}\text { EVT-based model } \\
\text { and POT method. }\end{array}$ & $\begin{array}{l}\text { Return of stock and } \\
\text { risk were connected } \\
\text { positively. }\end{array}$ \\
\hline Kumar (2018) & $\begin{array}{l}\text { Emerging stock } \\
\text { market }\end{array}$ & 2000 to 2014 & $\begin{array}{l}\text { Threshold- } \\
\text { GARCH }(1,1) \text { model }\end{array}$ & $\begin{array}{l}\text { There was a } \\
\text { negative } \\
\text { relationship } \\
\text { between stock } \\
\text { return and expected } \\
\text { volatility during the } \\
\text { post-crash periods. } \\
\text { There was a positive } \\
\text { relationship } \\
\text { between stock } \\
\text { return and } \\
\text { unexpected } \\
\text { volatility. }\end{array}$ \\
\hline Loudon (2017) & $\begin{array}{l}\text { Canada, France, } \\
\text { Germany, Italy, } \\
\text { Japan, the United } \\
\text { Kingdom and the } \\
\text { United states. }\end{array}$ & $\begin{array}{lr}\text { January } 1973 & \text { to } \\
\text { December } 2013 & \end{array}$ & $\begin{array}{l}\text { GARCH M and } \\
\text { Markov switching } \\
\text { regime model. }\end{array}$ & $\begin{array}{l}\text { Negative correlation } \\
\text { was found at stock } \\
\text { return and risk } \\
\text { while stock return } \\
\text { had positive } \\
\text { outcomes with } \\
\text { uncertainty of price } \\
\text { level. }\end{array}$ \\
\hline Lee (2017) & Australia & $\begin{array}{l}2 \text { March } 2011 \text { to } 18 \\
\text { May } 2016\end{array}$ & $\begin{array}{l}\text { C-GARCH-M } \\
\text { (component- } \\
\text { GARCH-Mean) } \\
\text { model. }\end{array}$ & $\begin{array}{lc}\text { Return } & \text { and risk } \\
\text { were } & \text { positively } \\
\text { related. } & \end{array}$ \\
\hline Hamid (2015) & Pakistan & 2000 to 2012 & $\begin{array}{lr}\text { GMM (Generalized } \\
\text { method } & \text { of } \\
\text { momentum) and } \\
\text { GLS (Generalized } \\
\text { least r square) } \\
\text { methods }\end{array}$ & $\begin{array}{l}\text { There was a } \\
\text { negative relation } \\
\text { between Return and } \\
\text { risk. }\end{array}$ \\
\hline $\begin{array}{ll}\text { Mustafa } & \text { and } \\
\text { Nishat }(2010) & \end{array}$ & Emerging market & 1991 to 2010 & GARCH & $\begin{array}{l}\text { Return had positive } \\
\text { linked with trading } \\
\text { volume }\end{array}$ \\
\hline Hyde (2007) & $\begin{array}{l}\text { France, Germany, } \\
\text { Italy and the UK }\end{array}$ & $\begin{array}{l}\text { January } 1973 \text { to } \\
\text { June 2004 }\end{array}$ & & $\begin{array}{l}\text { Stock returns were } \\
\text { positively related } \\
\text { with both and } \\
\text { exchange rate and } \\
\text { risk in four } \\
\text { countries. }\end{array}$ \\
\hline $\begin{array}{l}\text { Khiliji and Nabi } \\
\text { (1993) }\end{array}$ & Pakistan & $\begin{array}{l}\text { July } 1981 \text { to June } \\
1992\end{array}$ & CAPM & $\begin{array}{l}\text { Risk and return } \\
\text { were positively } \\
\text { related. }\end{array}$ \\
\hline
\end{tabular}

\section{Theoretical Framework: Capital Asset Pricing Model}

CAPM model defines the relationship between risk and returns. Risk is measured by standard deviation 
or variance of return while the excess return of monthly period represents risk premium which is formulated by taking difference of return of asset in which risk is present and risk-free asset in the same period. A simple form of CAPM can be written by following French et al. (1987) and Ahmad and Zaman (2000) as:

$E\left[\left(R E T_{R t}-R E T_{R F t}\right) \partial_{R}\right]=\lambda_{R}+\beta_{R}\left(\partial_{R}\right)^{k}+\mu_{t}, \quad \mathrm{k}=1,2$

Risky asset return is represented by $R E T_{R t}$ while risk free asset is shown by $R E T_{R F t}$, $\partial_{R}$ is variance of return on asset $\mathrm{R}$, prediction operator is $\mathrm{E}, \lambda_{R}$ and $\beta_{R}$ are parameters and $\mu_{t}$ is error term. As for as $\mathrm{k}=1$ and 2 are standard deviation or variance which means that excess covering time period of return linked with them.

- If $\lambda_{R}=\beta_{R}=0$, it means that zero expected risk premium while degree of volatility is high or low.

- If $\lambda_{R} \neq 0$ but $\beta_{R}=0$, this situation refers that the returns on risk free asset is different from the return on risky asset and the difference is due to other factors ${ }^{1}$ and it is not due to volatility.

- If $\beta_{R} \neq 0$ and $\lambda_{R}=0$, it means that volatility is related with the excess monthly returns.

- If $\beta_{R}>0$, the excess returns exhibit the risk premium while if $\beta_{R}<0$, volatility of returns on any asset is considered as incentive.

From the Equation 1, we replace standard deviation $\partial_{R}$ by sample estimate $S_{R}$ which is:

$R \square \square_{\square \square}-\square \square \square_{\square \square \square}=\square_{\square}+\square_{\square}\left(\square_{\square \square}\right)^{\square}+\square_{\square}$

(2)

We follow again French et al. (1987) and Ahmad and Zaman (2000) to calculate monthly standard deviation:

$S_{R t}=\left[\sum_{j=1}^{K_{t}}\left(r_{t j}\right)^{2}\right]^{1 / 2}$

In Equation (3) the monthly t trading term is presented by $K_{t}$ which is the number of days and the term return is showed by $\square_{\square \square}$ on day $\mathrm{j}$ of month $\mathrm{t}$. To calculate the daily variation in a month, we are aggregating variation of whole month which is not divisible with trade of daily data. Return of day to day is measured by serial correlation despite the use of formula of standard deviation presented by economists French et al, (1987) and Ahmad and Zaman (2000) that is shown in equation (4):

$S_{R t}=\left[\sum_{j=1}^{K_{t}}\left(r_{t j}\right)^{2}+2 \sum_{j=1}^{K_{t}} r_{t j} r_{t, j-1}\right]^{1 / 2}$

We are using formulas in equation (3) and (4) for measuring difference from mean, but results show that these formulas are not sufficient for measuring difference. If the results from Equation (4) are negative, we use Equation (3) instead of Equation (4).

Now we subdivide the standard deviation into anticipated standard deviation and anticipated error using ARIMA models. Risk is measured by anticipated standard deviation and uncertainty is measured by anticipated error of standard deviation, but it is unable to measure the volatility. (Chen et al., 1986 and French et al., 1987, Ahmad and Zaman (2000).

In Equation (5), by measuring the autocorrelation of four variables, we use variance instead of standard deviation of four variables. The autocorrelation coefficient of all the sectors of the first difference of standard deviation are eliminated by using four-month lag which are shown in Table 2 with moving average model.

$\left[(1-\square \square) \square_{\square \square}=\square_{\square 0}+\left[\sum_{\square=1}^{\square} \square \square(\square \square)^{\square}\right] \square_{\square}\right.$

In Equation (5) LG is used for lag and $\mathrm{k}$ represents the number of differences taking in the moving average formula. By getting the anticipated standard deviation of first difference, from the calculated

${ }^{1}$ i) disparity in transaction costs ii) premium on term structure of the risky and risk-free assets 
equation (5) we subtract the errors that is $\square_{\square \square}$, from previous measured values.

$\left[(1-L G) S_{R t}\right]^{A}=(1-L G) S_{R t}-e r_{t}$,

Following Equation (6) the $\mathrm{A}$ is the anticipated value and $\mathrm{t}$ is time period, by assuming we equal the first period of anticipated standard deviation with its original value $\square_{0}$ by converting the first differences into level and $\mathrm{A}$ is anticipated value that is presented in Equation (7):

$\left(S_{R t}\right)^{A}=S_{0}+\sum_{j=1}^{m}\left[(1-L G) S_{R j}\right]^{A}$

In Equation (7), $\square_{0}$ is the original value of standard devaition of the first month on the other hand $\mathrm{j}=1,2, \ldots$ In the end, our anticipation error is

$A E_{R t}=S_{R t}-\left(S_{R t}\right)^{A}$

Now we are interpreting the Equation (9), (10), (11) and (12) with the help of these equations we interpret the results of monthly returns of anticipated and unanticipated volatility shocks on asset which is explained in Equation (9), volatility, shocks and risk between sectors and overall market which are explained in Equation (10), returns on monthly in sectors and overall market are elucidated in Equation (11) and finally we explain the volatility relationship between particular stock return and whole market return which are described in Equation (12). In all these equations, we used CAPM.

Firstly, we are explaining the Equation (9) in which independent variable is $R E T_{R t}-\square \square \square \square$ which is difference between return on risky asset with return on risk free asset, while dependent variable is $\square_{\square}$ which is anticipated standard deviation of return, $\square_{\square}$ defines anticipated error prediction in standard deviation of return, $\square_{\square}$ is error term. Equation (9) is interpreted the risk premium, volatility, shocks and their results are shown in Table 2 and we also expected that the magnitude of parameter $\square \square$ and $\square_{\square}$ are positive.

$R E T_{R t}-R E T_{R F t}=\lambda_{R}+\beta_{R}\left(S_{R t}\right)^{A}+\eta_{R} A E_{R t}+\varepsilon_{t}, \quad$ A=anticipated

Next we are explaining the Equation (10) in which we are calculating the volatility of monthly return relationship between sectoral returns with whole market returns.

$R E T_{R t}-R E T_{R F t}=\lambda_{R}+b_{R}\left(S_{0 t}\right)^{A}+c_{R} A E_{0 t}+\varepsilon_{t}$,

Equation (10) the variables $\square_{0 \square}$ and $\mathrm{A} \square_{0 \square}$ determines the anticipated standard deviation and the anticipation error in standard deviation. In Eq (10) the parameters $\square_{\square}, \square_{\square}$ and $\square_{\square}$ their signs are not mentioned. The magnitude of parameter $\square_{\square}$ indicates the strength of risk in a market asset. If $\square_{\square}>0$ it means that there is proportionally increased in the return on asset $\mathrm{R}$ when the risk of whole market increases. Another way when $\square_{\square}<0$ indicates that in high market volatility the return on asset $\mathrm{R}$ is not much attractive for the investors. While when $\square_{\square}=0$ implies that return on asset $\mathrm{R}$ is free from the whole market volatility which is expected.

As for as we find out the relationship of ups and downs of return between specific sector and the whole market. For this aspect we are using the Equation (11) which interpret our results.

$R E T_{R t}-R E T_{R F t}=\delta_{R}+\theta_{R}\left(R E T_{0 t}-R E T_{F t}\right)+\varepsilon_{t}$,

Finally, we are discussing the relationship of volatility between specific assets of return with whole market return. We may analyze this relationship with the help of Equation (12).

$S_{R t}=\gamma_{R}+\gamma_{R V} S_{0 t}+\varepsilon_{t}, \quad \mathrm{~V}=\mathrm{l}=$ volatility

Now after stating the CAMP model, we turn our attention towards empirical results.

\section{Data and Methodology}

In this study, we have used the data of 10 sectors of Pakistan Stock Market. General indices and all the sectors indices are included, and their data are collected on daily and monthly basis during 2006 to 2014 from SBP. With the relative change of stock price indices, the rate of return on daily and monthly basis are calculated as month to month and day to day. Treasury bill rate is used as risk free interest rate because treasury bills maturity period is short, and rate of returns are fixed for the given period.

\section{Results and Discussions}


For interpretation of returns of variance for stochastic processes, for the level and the first difference of the variance besides the $\log$ of variance, we worked out up to $12^{\text {th }}$-order sample autocorrelation coefficients. Standard deviation is also calculated with same process. Results concluded that except first difference of standard deviation, using four months lag the coefficients of autocorrelation declines. While the autocorrelation coefficients are not linked up for other conditions. After these results, there is need of integrated moving average technique for the standard deviation series.

By using equation 5, the results of Table 2 are based on the correlograms and experiments, we analyze the integrated moving average of different orders for various sectors. The results of Table 2 indicate that there is significance on the most of parameters of MA technique. The value of t-statistics of all sectors are greater than unity which means that the specifications of MA process cannot be further curtailed with adjusted $R^{2}$. After these estimates, we have further divided the anticipated standard deviations of return and the anticipation error using equation (6), (7) and (8). These computed equations are further used for the estimation of different CAPM models. Equation (9) indicates the outcomes of CAPM model which are further discussed in Table 2. The results show that the magnitude of beta related with all sectors also with the anticipated standard deviation along with the anticipation error are positive and utmost sectors are statistically significant which means that there is a risk premium in the monthly excess return, when risk is high then anticipated return also high and the volatility is also anticipated high. Thus, there is a bad shock for investors but the reward for taking risk is risk premium that compensate all uncertainty. Furthermore, when the volatility reduces that is not foreseen in this respect, risk premium compensates all the risk.

The overall results show that in the market there is risk premium in the excess market return. High risk premium is anticipated in the sectors of Transport and Communication, Cotton and other Textiles, Engineering, Paper and Allied suggesting that the investors take more amount of risk which is greater than the actual amount of risk in these sectors. So in these sectors, the investors are risk lovers. Low risk premium is anticipated in the sectors of Cement, Cable and Electric Goods, Auto and Allied, Sugar suggesting that investors are risk averse and they do not want to take any amount of risk in these sectors. Additionally, the sectors in which the reward for risk is high when there is high volatility which is unanticipated as well as that sector volatility become low which is not expected and in that sector the reward for risk is also low. (Ahmad and Zaman, 2000).

Table 2: Integrated Moving Average (MA) Models for Selected Sectors

\begin{tabular}{|l|c|c|c|c|c|c|c|l|}
\hline \multicolumn{9}{|c|}{ Dependent Variable: d(SD of Returns) } \\
\hline Sectors & $\boldsymbol{\varphi}_{\mathbf{R} 0}$ & $\boldsymbol{\varphi}_{\mathbf{R} 1}$ & $\boldsymbol{\varphi}_{\mathbf{R} 2}$ & $\boldsymbol{\varphi}_{\mathbf{R} 3}$ & $\boldsymbol{\varphi}_{\mathbf{R} 4}$ & $\begin{array}{c}\text { Prob. } \\
(\text { F-Stat })\end{array}$ & $\mathbf{R 2}$ & $\mathbf{D W}$ \\
\hline $\begin{array}{l}\text { Transport \& } \\
\text { Communication }\end{array}$ & -0.1825 & $-0.4814^{* *}$ & $-0.786^{* *}$ & ---- & ---- & 0.0000 & 0.4304 & 1.9571 \\
\hline Fuel and Energy & -0.4088 & $-0.929^{* * *}$ & $-0.690^{* * *}$ & $0.1354^{* *}$ & $-0.8592^{*}$ & 0.0001 & 0.5812 & 2.1683 \\
\hline $\begin{array}{l}\text { Cotton \& Other } \\
\text { Textiles }\end{array}$ & 0.6652 & $-0.685^{* * *}$ & $-0.038^{* *}$ & $-0.989^{* * *}$ & ---- & 0.0000 & 0.5484 & 2.0417 \\
\hline Sugar & 0.1385 & $-0.7426^{* *}$ & $-0.3406^{*}$ & $0.9223^{*}$ & ----- & 0.0000 & 0.3206 & 2.1864 \\
\hline Cement & -0.5219 & $-0.9530^{*}$ & ---- & ----- & ---- & 0.0005 & 0.2338 & 1.9994 \\
\hline Engineering & -0.6425 & $-0.3302^{*}$ & ----- & ----- & ---- & 0.0000 & 0.3165 & 2.1150 \\
\hline $\begin{array}{l}\text { Cable \& Electric } \\
\text { Goods }\end{array}$ & 0.4857 & $-0.0603^{* *}$ & $-0.5142^{*}$ & $0.5075^{*}$ & $-0.900^{* *}$ & 0.0000 & 0.4801 & 2.1286 \\
\hline Paper \& Allied & 0.6742 & $-0.829^{* * *}$ & ----- & ----- & ----- & 0.0000 & 0.3579 & 1.8606 \\
\hline Auto \& Allied & -0.2014 & $-0.3183^{* *}$ & ----- & ----- & ---- & 0.0080 & 0.2207 & 2.1321 \\
\hline $\begin{array}{l}\text { Chemicals \& } \\
\text { Pharmaceuticals }\end{array}$ & -0.4623 & $-0.1270^{*}$ & ---- & ---- & ---- & 0.0300 & 0.3679 & 2.1756 \\
\hline $\begin{array}{l}\text { Overall Market } \\
\text { Index }\end{array}$ & -0.6876 & $-0.0373^{*}$ & $-0.2406^{*}$ & ----- & ---- & 0.0000 & 0.4834 & 2.0605 \\
\hline
\end{tabular}

$* * * * * *$ are $1 \%, 5 \%$ and $10 \%$. 
Table 3 exhibits that the magnitude of lambda is positive in the cement sector, Cable \& Electric Goods and auto and allied sector implying that there is a no risk in the excess monthly return, when there is any risk anticipated then the return on excess market will be negative. As treasury bills maturity period is long-lasting in contrast with assets of stock market which are exchangeable with any time so above results are forecasted. Accordingly, treasury bill can be the reward of taking risk in the excess monthly return because these treasury bills compensate all loss when the investor takes the risk (Ahmad and Zaman, 2000).

Table 3: Anticipated Volatility (Risk) and Unanticipated Volatility Shocks (Uncertainty) of Excess Monthly Returns

\begin{tabular}{|l|c|c|c|c|c|c|}
\hline \multicolumn{7}{|c|}{ Dependent Variable: $\left(\mathbf{R E T}_{\mathbf{R t}}-\mathbf{R E T}_{\mathbf{R f t}}\right)$} \\
\hline Sectors & $\boldsymbol{\lambda}_{\mathbf{R}}$ & $\boldsymbol{\beta}_{\mathbf{R}}$ & $\boldsymbol{\eta}_{\mathbf{R}}$ & $\begin{array}{c}\text { Prob. } \\
\text { (F-Stat) }\end{array}$ & $\mathbf{R 2}$ & $\mathbf{D W}$ \\
\hline Transport \& Communication & $-0.5189^{*}$ & 0.2274 & $0.5642^{* * *}$ & 0.0045 & 0.1881 & 2.35 \\
\hline Fuel and Energy & $-0.6517^{* *}$ & $0.1225^{*}$ & $0.3106^{* *}$ & 0.0033 & 0.1140 & 2.03 \\
\hline Cotton \& Other Textiles & $-0.4929^{*}$ & $0.2225^{*}$ & $0.8414^{* *}$ & 0.0100 & 0.4219 & 2.06 \\
\hline Sugar & $-0.3309^{*}$ & $0.1803^{* *}$ & 0.0199 & 0.0000 & 0.1540 & 1.94 \\
\hline Cement & $0.4564^{*}$ & $0.8079^{* * *}$ & $0.7386^{*}$ & 0.0398 & 0.3639 & 1.88 \\
\hline Engineering & -0.1747 & $0.7815^{*}$ & $0.7877^{* *}$ & 0.0000 & 0.1677 & 1.99 \\
\hline Cable \& Electric Goods & $0.6032^{*}$ & $0.4317^{* *}$ & $0.7224^{*}$ & 0.0024 & 0.4756 & 1.97 \\
\hline Paper \& Allied & $-0.6707^{*}$ & $0.8783^{* *}$ & $0.3750^{*}$ & 0.0005 & 0.4966 & 1.87 \\
\hline Auto \& Allied & 0.5917 & $0.2113^{*}$ & $0.4424^{* *}$ & 0.0001 & 0.2820 & 1.94 \\
\hline Chemicals \& Pharmaceuticals & $-0.1643^{* *}$ & $0.4586^{* * *}$ & $0.0521^{*}$ & 0.0000 & 0.2642 & 1.88 \\
\hline Overall Index & $-0.4740^{* *}$ & $0.4777^{* *}$ & $0.2666^{* *}$ & 0.0000 & 0.1402 & 2.17 \\
\hline$* * * * *$ are 1\%, 5\% and 10\%. & & & & &
\end{tabular}

Next, we are interpreting the relationship between the excess monthly return of individual sector and its effects on overall market. To explain how the whole market earns profit or return with the profit of separate sector of the market, we have used equation 10 and its results are shown in Table 4. In Table 4, $\lambda_{\square}$ is risk $\square_{\square}$ is anticipated SD of return on general index and $\square_{\square}$ is anticipated error in SD of return on general index. Table 4 interprets the results of standard deviation of return on general index and anticipated error in standard deviation on general index.

The results show that in all sectors except two sectors the value of lambda is negative and the value of $\square_{\square}$ and $\square_{\square}$ are positive which means that the excess monthly return contains risk premuim in the overall market. The value of $\square_{\square}$ which is error prediction in the standard deviation of returns is positive means that the investors are risk lovers and they compensate their uncertainty risk with the reward of risk premium. On the other hand, cement sector and Chemicals and Pharmaceuticals sector their magnitude of lambda is positive. The results show that the value $\square_{\square}$ is positive which means that there is no risk in the excess monthly return of asset of the individual sector. The results show that the volatility and the uncertainty in the overall market is not significant influencing on the rates of return on asset of individual sectors (Zou and Adam, 2008; Ahmad and Zaman, 2000).

Table 4: Anticipated Volatility (Risk) and Unanticipated Volatility Shocks (Uncertainty) of Sectoral Excess Monthly Returns in Overall Market

\begin{tabular}{|l|c|c|c|c|c|c|}
\hline \multicolumn{7}{|c|}{ Dependent Variable: $\left.\mathbf{R E T}_{\mathbf{R t}}-\mathbf{R E T}_{\mathbf{R f t}}\right)$} \\
\hline Sectors & $\lambda_{\mathbf{R}}$ & $\mathbf{b}_{\mathbf{R}}$ & $\mathbf{c}_{\mathbf{R}}$ & $\begin{array}{c}\text { Prob. } \\
\text { (F-Stat) }\end{array}$ & $\mathbf{R 2}$ & $\mathbf{D W}$ \\
\hline Transport \& Communication & $-0.1331^{* *}$ & $0.5630^{*}$ & $0.7867^{* *}$ & 0.0115 & 0.1444 & 1.67 \\
\hline Fuel and Energy & $-0.6333^{* *}$ & $0.6583^{*}$ & $0.3508^{* * *}$ & 0.0430 & 0.3579 & 1.45 \\
\hline
\end{tabular}




\begin{tabular}{|l|c|c|c|c|c|c|} 
Cotton \& Other Textiles & -0.7080 & $0.6370^{*}$ & $0.4000^{* *}$ & 0.0826 & 0.2777 & 1.35 \\
\hline Sugar & -0.3074 & 0.7883 & $0.2103^{*}$ & 0.0194 & 0.2354 & 1.94 \\
\hline Cement & $0.9644^{* *}$ & $0.7920^{* * *}$ & 0.4960 & 0.0057 & 0.0096 & 1.51 \\
\hline Engineering & $-0.6935^{*}$ & $0.7781^{* *}$ & $0.4755^{*}$ & 0.0971 & 0.1770 & 1.78 \\
\hline Cable \& Electric Goods & $-0.293^{* * *}$ & $0.0258^{*}$ & $0.7940^{* *}$ & 0.0195 & 0.1533 & 1.41 \\
\hline Paper \& Allied & $-0.1489^{* *}$ & 0.7236 & $0.0993^{* *}$ & 0.0858 & 0.2739 & 1.97 \\
\hline Auto \& Allied & $-0.327^{* * *}$ & $0.5859^{*}$ & $0.9656^{*}$ & 0.0455 & 0.2152 & 1.88 \\
\hline Chemicals \& Pharmaceuticals & $0.5400^{* *}$ & 0.8959 & $0.0578^{* *}$ & 0.0752 & 0.2837 & 1.66 \\
\hline
\end{tabular}

$* * * * * *$ are $1 \%, 5 \%$ and $10 \%$.

The results show that the investors in the individual sector are willing to receive the high risk with the high increased anticipated volatility in the overall market. The unanticipated volatility shock in the overall market exists when the uncertainty of return increases in these sectors. Furthermore, the demand of asset of a particular sector declines up to the reward of risk premium to compensate the all-risk that is increased. Similarly, it is expected that when the particular sector is received high return that is not certain, it results in high volatility shock that is not anticipated in the overall stock market (Zou and Adam 2008; Ahmad and Zaman, 2000).

Now we are discussing the effects of returns on asset in both individual sector and overall market return. Furthermore. we are examining the relationship between individual returns and overall market return on monthly bases. All these results are present in Table 5 by using equation 11 .

Table 5: Sectorial Excess Monthly Returns and Returns with Overall Market Index

\begin{tabular}{|l|c|c|c|c|c|}
\hline \multicolumn{5}{|c|}{ Dependent Variable: $\left(\mathbf{R E T}_{\mathbf{R t}}-\mathbf{R E T}_{\mathbf{R f t}}\right)$} \\
\hline Sectors & $\boldsymbol{\delta}_{\mathbf{R}}$ & $\boldsymbol{\theta}_{\mathbf{R}}$ & $\begin{array}{c}\text { Prob. } \\
(\mathbf{F}-S t a t)\end{array}$ & $\mathbf{R 2}$ & DW \\
\hline Transport \& Communication & $-0.5739^{* *}$ & $0.9588^{* * *}$ & 0.7657 & 0.55 & 2.10 \\
\hline Fuel and Energy & $0.6292^{*}$ & $0.3539^{* *}$ & 0.1478 & 0.84 & 2.11 \\
\hline Cotton \& Other Textiles & $0.0915^{*}$ & 0.6382 & 0.6015 & 0.79 & 2.24 \\
\hline Sugar & $-0.9896^{*}$ & $0.3709^{* *}$ & 0.8944 & 0.82 & 2.47 \\
\hline Cement & $-0.591^{* * *}$ & $0.8182^{*}$ & 0.6597 & 0.68 & 2.15 \\
\hline Engineering & -0.1923 & $0.7748^{* *}$ & 0.6692 & 0.62 & 1.93 \\
\hline Cable \& Electric Goods & $-0.6368^{* *}$ & $0.0946^{*}$ & 0.3756 & 0.52 & 1.65 \\
\hline Paper \& Allied & $-0.0030^{* *}$ & $0.4456^{*}$ & 0.2145 & 0.86 & 2.59 \\
\hline Auto \& Allied & $-0.3027^{*}$ & 0.0381 & 0.6439 & 0.83 & 1.69 \\
\hline Chemicals \& Pharmaceuticals & $-0.7433^{*}$ & $0.3854^{* *}$ & 0.7383 & 0.59 & 2.16 \\
\hline
\end{tabular}

$* * * * * *$ are $1 \%, 5 \%$ and $10 \%$.

In Table 5, we examine the relationship between returns of individual sector and overall market and results show that in all sectors the relationship between the returns of individual sector with the returns of overall market are positive and significant. The rate of return of overall market positively rises and falls with the rise and fall of returns of individual sector. On contrary, it is noted that how the market trends efficiently work with daily variations or monthly variations while studies examine that market trend is not work efficiently with daily variations of stock returns but during the period of one month stock of returns of sectors follow the market trend. Results point out that there is a competitive trading activity in a Pakistan Stock Market (Ahmad and Zaman, 2000; Lyocsal et al. 2018).

Finally, Table 6 discusses the volatility effect in the sectorial and overall market. The results exhibit that there is positive relationship between the standard deviation of monthly excess returns of individual sectors and overall market. The values of $\square_{\square}$ and $\square_{\square \square}$ are positive in mostly sectors except two sectors in which the value of $\square_{\square}$ (standard deviation of monthly excess returns of individual sector) is negative and these sectors are Fuel and Energy, and Cable and Electric Goods. But the overall average of these 
sectors is positive which indicates that the individual sectors of excess returns of standard deviation is positively related with the overall market of excess returns of standard deviation. It means that the volatility of individual sector complies with market trend suggesting that there is speculation when there is volatility in the stock market (Khan, 2016).

Table 6: Returns on Sectorial and Overall Market Volatility

\begin{tabular}{|c|c|c|c|c|c|}
\hline \multicolumn{6}{|c|}{ Dependent Variable: (SD of Excess Returns) } \\
\hline Sectors & $\gamma_{\mathrm{R}}$ & $\gamma_{\mathrm{RV}}$ & $\begin{array}{c}\text { Prob. } \\
\text { (F-Stat) }\end{array}$ & $\mathbf{R 2}$ & DW \\
\hline Transport \& Communication & $0.3085^{* *}$ & $0.5290^{*}$ & 0.9878 & 0.18 & 1.77 \\
\hline Fuel and Energy & $-0.4642^{*}$ & $0.0482^{* * * *}$ & 0.0483 & 0.47 & 1.69 \\
\hline Cotton \& Other Textiles & $0.4850^{* *}$ & 0.9710 & 0.8748 & 0.13 & 1.96 \\
\hline Sugar & $0.2686^{*}$ & $0.6772^{*}$ & 0.2953 & 0.19 & 1.84 \\
\hline Cement & $0.7272^{* *}$ & $0.7566^{* * *}$ & 0.2076 & 0.39 & 1.48 \\
\hline Engineering & $0.6516^{* *}$ & $0.5583^{*}$ & 0.2514 & 0.68 & 1.64 \\
\hline Cable \& Electric Goods & $-0.036^{* * *}$ & $0.6311^{*}$ & 0.5085 & 0.41 & 1.90 \\
\hline Paper \& Allied & $0.0136^{*}$ & $0.1804^{* * *}$ & 0.7472 & 0.35 & 1.87 \\
\hline Auto \& Allied & $0.2645^{* *}$ & $0.1838^{* * *}$ & 0.0706 & 0.26 & 1.79 \\
\hline Chemicals \& Pharmaceuticals & $0.9471^{* *}$ & $0.1631^{*}$ & 0.1701 & 0.33 & 1.43 \\
\hline
\end{tabular}

The result exhibit that market trend is followed by sectorial returns implying that Pakistan Stock Market is significantly influenced in the presence of trading decision and financial market is influenced by external shocks in which whole market is affected symmetrically suggesting that when shocks exist in the asset, these shocks badly affect the whole market returns. In a nutshell, the results conclude that there are no asymmetric information in the market.

\section{Conclusions and Policy Recommendations}

In this study, we have examined the link among excess monthly returns, uncertainty and risk factors by using Capital Asset Pricing Model (CAPM) model for 10 sectors of Pakistan Stock Market. We have used monthly data over the period of 2005 to 2016. We have examined the dependence of level of sector volatility on individual sectors and overall stock market. The analysis shows that the level of volatility of particular sector depends on the excess monthly returns of each sector and overall stock market volatility. Furthermore, there is risk premium in the individual sector returns which causes the anticipated risk in the discrete sector and overall stock market. Moreover, the unanticipated volatility shocks overhaul with the rates of returns when sectors received in individual sector and overall stock market. The discrete sectors and overall stock market follow same oscillating trends in the long run suggesting that rate of returns in various sector have reacted same way with the overall stock market performance. Moreover, the volatility factor is also included in discrete sectors and these sectors also go with the same trend of market. The broad conclusion of the study is that volatility factor is high in the overall stock market and the level of volatility in different sectors of the market moves in the same direction which suggest that speculative activities are widely spread in every sector and in overall market as well.

Prudent decisions can be made by observing the fact that most of the investors are risk averse due to their behavior and presence of risk premium and the compensation of unanticipated shocks in Pakistan Stock Market. Additionally, same oscillating trends indicate that there is high competition in Pakistan Stock Market and trading activities are based on the strengths and weakness of investors. In summary, we may conclude that Pakistan stock market is a volatile and vigorous market and it follows the bandwagon effect.

\section{References}

Abounoori, E., \& Tour, M. (2019). Stock market interactions among Iran, USA, Turkey, and 
UAE. Physica A: Statistical Mechanics and its Applications, 524, 297-305.

Aggarwal, R. (1979). Multinationality and stock market valuation: an empirical study of US markets and companies. Management International Review, 5-21.

Ahmad, E., \& Rosser, B. J. (1995). Non-linear speculative bubbles in the Pakistan stock markets. Pakistan Development Review, 34(1), 25-41.

Ahmad, E., \& Zaman, B. (2000). Risk, Uncertainty and Returns at the Karachi Stock Exchange.

Ahmad, E., \& Zaman, B. U. (1999). Volatility and Stock Returns at Karachi Stock Exchange. Pakistan Economic and Social Review, 25-37.

Akhtar, S., \& Khan, N. U. (2016). Modeling volatility on the Karachi Stock Exchange, Pakistan. Journal of Asia Business Studies, 10(3), 253-275.

Akmal, M. S. (2007). Stock Returns and Inflation: An ARDL econometric investigation utilizing Pakistani data. Pakistan Economic and Social Review, 45(1), 89-105.

Atindéhou, R. B., \& Gueyie, J. P. (2001). Canadian chartered banks'stock returns and exchange rate risk. Management Decision, 39(4), 285-295.

Bagirov, M., \& Mateus, C. (2019). Oil prices, stock markets and firm performance: Evidence from europe. International Review of Economics \& Finance, 61, 270-288.

Chiang, T. C. (2019). Economic policy uncertainty, risk and stock returns: Evidence from G7 stock markets. Finance Research Letters, 29(C), 41-49.

Demirovic, A., Guermat, C., \& Tucker, J. (2017). The relationship between equity and bond returns: An empirical investigation. Journal of Financial Markets, 35, 47-64.

Dockery, E., Vergari, D., \& Vergari, F. (2001). Explaining the behaviour of stock prices in an emerging market: an empirical analysis of the Greek stock market. Managerial Finance, 27(1/2), 82-98.

El- Masry, A., \& Hyde, S. (2007). The response of industry stock returns to market, exchange rate and interest rate risks. Managerial Finance.

Fabozzi, F. J., \& Modigliani, F. (2003). Capital markets: institutions and instruments. Pearson College Division.

Farooq, M. T., Keung, W. W., \& Kazmi, A. A. (2004). Linkage between Stock Market Prices and Exchange Rate: A Causality Analysis for Pakistan [with Comments]. The Pakistan Development Review, 639-649.

Garlappi, L., Shu, T., \& Yan, H. (2006). Default risk, shareholder advantage, and stock returns. The Review of Financial Studies, 21(6), 2743-2778.

Gitman, L. J., Juchau, R., \& Flanagan, J. (2015). Principles of managerial finance. Pearson Higher Education AU.

Gourène, G. A. Z., Mendy, P., \& Ake, G. M. N. G. (2019). Multiple time-scales analysis of global stock markets spillovers effects in African stock markets. International Economics, 157, 82-98.

Habib-Ur-Rahman, \& Mohsin, H. M. (2012). Momentum effect: empirical evidence from Karachi stock exchange. The Pakistan development review, 449-461.

Haesen, D., Houweling, P., \& van Zundert, J. (2017). Momentum spillover from stocks to corporate bonds. Journal of Banking \& Finance, 79, 28-41.

Husain, F., \& Mahmood, T. (2001). The stock market and the economy in Pakistan. The Pakistan Development Review, 107-114.

Husain, F., \& Uppal, J. (1998). Distribution of stock returns in an emerging market: The Pakistani market. Pakistan Economic and Social Review, 47-72.

Hussain, F., \& Qasim, M. A. (1997). The Pakistani equity market in 50 years: a review. The Pakistan Development Review, 863-872.

Javaira, Z., \& Hassan, A. (2015). An examination of herding behavior in Pakistani stock market. International journal of emerging markets, 10(3), 474-490.

Javid, A. Y., \& Ahmad, E. (2011). Asset pricing behaviour with dual-beta in case of Pakistani stock market. The Pakistan Development Review, 95-118.

Khan, S. U., \& Hijzi, S. T. (2009). Single stock futures trading and stock price volatility: Empirical analysis. The Pakistan Development Review, 48(4-II), pp-553.

Khilji, N. M., \& Nabi, I. (1993). The Behaviour of Stock Returns in an Emerging Market: A Case Study 
of Pakistan [with Comments]. The Pakistan Development Review, 32(4), 593-604.

Kumar, R. (2018). Risk, uncertainty and stock returns predictability-a case of emerging equity markets. Journal of Financial Economic Policy, 10(4), 438-455.

Lee, C. L. (2017). An examination of the risk-return relation in the Australian housing market. International Journal of Housing Markets and Analysis, 10(3), 431-449.

Lin, F. L., Yang, S. Y., Marsh, T., \& Chen, Y. F. (2018). Stock and bond return relations and stock market uncertainty: evidence from wavelet analysis. International Review of Economics \& Finance, 55, 285-294.

Loudon, G. (2017). The impact of global financial market uncertainty on the risk-return relation in the stock markets of G7 countries. Studies in Economics and Finance, 34(1), 2-23.

Lyócsa, Š., Molnár, P., \& Plíhal, T. (2019). Central bank announcements and realized volatility of stock markets in G7 countries. Journal of International Financial Markets, Institutions and Money, 58, 117-135.

Maghyereh, A. I., \& Al-Zoubi, H. A. (2008). The tail behavior of extreme stock returns in the Gulf emerging markets: An implication for financial risk management. studies in Economics and Finance, 25(1), 21-37.

Messis, P., \& Zapranis, A. (2014). Herding behaviour and volatility in the Athens Stock Exchange. The Journal of Risk Finance, 15(5), 572-590.

Mohammad Khan Ghauri, S. (2014). Determinants of changes in share prices in banking sector of Pakistan. Journal of Economic and Administrative Sciences, 30(2), 121-130.

Moore, T. (2007). The Euro and stock markets in Hungary, Poland, and UK. Journal of Economic Integration, 69-90.

Mustafa, K., \& Nishat, M. (2010). Risk, return and trading volume relationship in an emerging stock market: a case study of Karachi stock exchange. Savings and Development, 147-168.

Prasad, N., Grant, A., \& Kim, S. J. (2018). Time varying volatility indices and their determinants: Evidence from developed and emerging stock markets. International Review of Financial Analysis, 60, 115-126.

Rashid, A., \& Hamid, F. (2015). Downside risk analysis of returns on the Karachi Stock Exchange. Managerial Finance, 41(9), 940-957.

Raza, S. A., Jawaid, S. T., Afshan, S., \& Karim, M. Z. A. (2015). Is stock market sensitive to foreign capital inflows and economic growth? Evidence from Pakistan. Journal of Chinese Economic and Foreign Trade Studies, 8(3), 142-164.

Robinson, J. (2005). Stock price behaviour in emerging markets: Tests for weak form market efficiency on the Jamaica Stock Exchange. Social and Economic Studies, 51-69.

Shahzad, S. J. H., Raza, N., Shahbaz, M., \& Ali, A. (2017). Dependence of stock markets with gold and bonds under bullish and bearish market states. Resources Policy, 52, 308-319.

Sharif, S. (2015). Market reaction to the Karachi stock exchange floor imposition. South Asian Journal of Global Business Research, 4(2), 275-291.

Simlai, P. (2009). Stock returns, size, and book-to-market equity. Studies in Economics and Finance, 26(3), 198-212.

Singhania, M., \& Prakash, S. (2014). Volatility and cross correlations of stock markets in SAARC nations. South Asian Journal of Global Business Research, 3(2), 154-169.

Sohail, N., \& Hussain, Z. (2009). Long-Run and Short-Run Relationship between Macroeconomic Variables and Stock Prices in Pakistan. Pakistan Economic and Social Review, 47(2), 183-198.

Tissaoui, K., \& Azibi, J. (2019). International implied volatility risk indexes and Saudi stock returnvolatility predictabilities. The North American Journal of Economics and Finance, 47, 65-84.

Van Horne James, C. (2002). Financial Management \& Policy, 12/E. Pearson Education India.

Yong Fu, T., Holmes, M. J., \& Choi, D. F. (2011). Volatility transmission and asymmetric linkages between the stock and foreign exchange markets: A sectoral analysis. Studies in Economics and Finance, 28(1), 36-50.

Zou, H., \& Adams, M. B. (2008). Corporate ownership, equity risk and returns in the People's Republic of China. Journal of International Business Studies, 39(7), 1149-1168. 